\title{
MENAS VIEŠOSIOSE MIESTO ERDVĖSE: KŪRĖJO, UŽSAKOVO IR PUBLIKOS VERTYBIŲ SANDRAUGOS KLAUSIMAS
}

\author{
Elona Lubyte் \\ Vilniaus dailès akademija, UNESCO kultūros vadybos ir kultūros politikos katedra, \\ Maironio g. 6, 01124 Vilnius, Lietuva \\ Elpaštaslelona@email.lt \\ Iteikta 20101210
}

\begin{abstract}
Santrauka. Viešosios miesto erdvès atspindi vertybines visuomenės (kūrejjo, užsakovo ir publikos) nuostatas. Pereinant iš sovietmečio planinès ekonomikos ị rinkos santykius, nuo politiškai reglamentuotos link demokratinès kūrybinès raiškos ịvairovès, centralizuotą valstybinių užsakymų sistemą keičia liberalesnè meno kūrinių viešosiose erdvėse užsakymo sistema.

Todèl šiandien viešoji miesto erdvè turètų tapti skirtingų pasaulěžiūrinių vertybinių meninių programų pateikimo platforma. Tačiau kol kas santykiams tarp skirtingų meninių programų kūrẻjų, užsakovų ir publikos būdinga ne demokratinė tolerancija, o šaltojo karo (kas ne su mumis, tas prieš mus, t. y. mūsų priešas) pozicija.

Ieškant šio reiškinio priežasčių, pasitelkus socialinių mokslų (vadybos, marketingo) tyrimų metodus (PEST, SSGG, stebëjimą ir atvejų analizę), pranešime aptariamos kūrèjo, užsakovo ir publikos pasaulėžiūrinių vertybių sąsajos su šiuolaikinės skulptūros viešosiose miesto erdvėse raiška (nuo monumentalios reprezentacijos link skirtų konkrečiai vietai meno objektų (site-specific art object) ir socialiai angažuotos (socially engaged) kūrybos). Tuo tikslu sutelkiamas dèmesys ị skirtingų nūdienos meninių programų ir partnerystès modelių (jie yra tokie: posovietinis, liberalus, naujosios kairés, mokymosi iš Las Vegaso, politinés apropriacijos) vertybių prieštarų priežastis.
\end{abstract}

Reikšminiai žodžiai: menas viešosiose miesto erdvėse, kūrejas, užsakovas, publika, posovietinis, liberalus, naujosios kairès, mokymosi iš Las Vegaso, politinès apropriacijos modeliai.

\section{Ivadas}

Viešosiose miesto erdvėse lyg veidrodyje atsispindi skirtingų socialinių grupių pasaulèžiūros vertybès. Tai reiškia, kad demokratėjančioje Lietuvoje viešoji miesto erdvè turètų ir (ar) galètų tapti modernia, atvira skirtingų vertybių ir (ar) meninių programų platforma. Tačiau kol kas santykiai tarp skirtingų meninių programų kūrẻjų, užsakovų ir publikos nèra pagrịsti tolerantiškumu požiūrių ịvairovei bei plètojasi šaltojo karo (kas ne su mumis, tas prieš mus) aplinkoje.

Šio tyrimo objektas - rinkos sąlygomis pasireiškiančios skirtingų meninių programų kūrèjų, užsakovų ir publikos vertybẻs bei jų prieštarų priežastys. Tyrimo tikslas - pagrịsti skirtingų socialinių grupių (kūrèjo, užsakovo ir publikos) vertybių sandraugos bū- tinybę Lietuvoje. Tyrimo tikslui pasiekti išsikelti šie uždaviniai:

- apžvelgti kūrëjo, užsakovo ir publikos vertybių sandraugos kaitą XX-XXI a.;

- aptarti Lietuvoje mene vykstančias vertybines permainas pereinant iš planinès ị rinkos ekonomiką;

- nustatyti nepriklausomybès laikais pasireiškiančius kūrejjo, užsakovo ir publikos vertybių sandraugos modelius.

Išsikeltiems uždaviniams ịgyvendinti pasitelkti socialinių mokslų (vadybos ir rinkodaros) tyrimų metodai, leidžiantys skirtingų socialinių grupių (kūrèjų, užsakovų ir publikos) vertybių sandraugos klausimus nagrinèti siejant išorinès, arba makroaplinkos - po- 
litinès, ekonominès, sociokultūrinès, technologinès (PEST) - ir nūdienos vidinès, arba mikroaplinkos meno lauko stiprybių, silpnybių, grèsmių ir galimybių (SSGG) - analizes. Atlikus rinkos persiskirstymo tyrimą siekiama aptarti senus (posovietinius) ir naujus (liberalius), pasireiškiančius pavieniui (naujosios kairés, mokymosi iš Las Vegaso, politines apropriacijos) kūrejjo, užsakovo ir publikos vertybių sandraugos modelius.

Tyrimo tarpdalykiškumas lèmé, kad buvo gretinami skirtingi literatūros šaltiniai (filosofijos, socialinių mokslų, dailètyros bei analitinès naujųjų laikų publicistikos). Siekiant susieti Vakarų ir Lietuvos modernizacijos procesus remtasi XX a. modernizmo priešaušrio filosofo Jose Ortega y Gasset ir XX a. pabaigos postmodernizmo filosofo Frederic Jameson darbais. Ivardinant naujųjų (nepriklausomybès) laikų permainas Lietuvoje pasitelkti išeivijos politologo Kęstučio Girniaus ir filosofo, kultūros kritiko bei idèjų istoriko Leonido Donskio požiūriai, išryškinantys „vèluojančios modernizacijos“ priežastis ir pasekmes. Pasirenkant socialinių mokslų tyrimų metodus remtasi rinkodaros klasiko Philip Kotler, kultūros vadybos pokyčių Rytų ir Vidurio Europoje tyrinètojos Milena Dragicevič Šešič darbais. Svarbiu šaltiniu aiškinantis meno viešosiose miesto erdvèse raidos problemas tapo $\mathrm{XX}$ a. pokyčius tyrinëjusių užsienio (Rosalind Krauss, Cher Krause Knight, W. J. T. Michell) ir Lietuvos (Giedrès Jankevičiūtès, Laimos Kreivytès, Audriaus Novicko, Skaidros Trilupaitytès) autorių darbai.

\section{Kodèl svarbus kūrèjo, užsakovo ir publikos vertybių sandraugos klausimas?}

Svarstant naujųjų (nepriklausomybès) laikų permainas, vykusias ar vykstančias pereinant iš planinès $\mathfrak{i}$ rinkos ekonomiką, daugiau demesio skiriama sistemai ir institucijoms, o ne žmogui. Permainos yra socialinis procesas, kurio pagrindinis dalyvis yra žmogus, o jo sèkmę lemia jo žinios, suvokimas, ką ir kodèl būtina keisti, noras (troškimas) keisti ir ketinimas (valia) keisti, igūdžiai bei gebèjimai, parodantys, kaip keistis. Todèl šiame procese labai svarbūs vertybinių nuostatų klausimai. Jų aktualumą lemia Lietuvoje tebevykstantis perejjimas nuo ideologiškai reglamentuotos link demokratinès vertybių ir požiūrių ịvairovès. Sovietinių metų „neklasineje visuomenejje, kurioje yra viena bendrai liaudžiai priklausanti nuosavybè ir visiška socialinè lygybë“ (Marshal 1994: 399), skirtingomis vertybèmis pagrista grupiniu (bendruomeninių) interesu įvairovè nebuvo pripažistama. Tai prieštaravo žmogaus prigimčiai, nes būdami skirtingi, žmonès turi ivairius poreikius, pomėgius, tiksliau vertybes bei jas išreiškiančius norus. „Žmogaus norai - tai forma, kurią igyja žmogaus poreikis aplinkos ir asmenybès itakoje. <...> Norus formuoja visuomenè ir jie gali būti apibūdinti daiktais [arba kūriniais - E. L.], kurie gali patenkinti tuos poreikius. Kylant visuomenès gerovei, jos narių norai didejja. Kai atsiranda galimybès žmonèms įsigyti daugiau daiktų, keliančių jų susidomejimą bei norą įsigyti, gamintojai stengiasi pateikti daugiau norus patenkinančių gaminių bei paslaugų" (Kotler ir kt. 2003: 26).

Sovietiniais metais „liaudiškos formos, socialistinio (ideologinio) turinio" menas viešosiose miesto erdvèse (paminklai, dekoratyvinè skulptūra) reprezentavo totalitarinę valstybę. O meninių sprendimų paklausa ir pasiūla išreiške autokratinę, centralizuotą ideologinio užsakovo valią ir galią pavaldiems menininkams. Meno kūrinių viešosiose miesto erdvese užsakymų skyrimą ir igyvendinimą kontroliavo Meno taryba, kurią sudarè skirtingų grandžių (SSSR pavaldaus LSSR ministrų tarybos kultūros skyriaus, LSSR kultūros ministerijos, LSSR dailininkų sąjungos vadovų, skulptūros sekcijos pirmininkų ir kt.) partinès nomenklatūros atstovai. Visuomenè (publika) nedalyvavo svarstant miete atsirandančių kūrinių projektus bei juos atrenkant, tačiau buvo privalomai itraukiama ì masinį dalyvavimą reprezentaciniuose ideologinès sistemos ritualuose: paminklų atidengimo, iškilių metinių paminèjimo, vainikų, gèlių dejjimo ceremonijose. Anuomet ne itin plètota alternatyvi seminonkonformistine, tyliojo modernizmo kūrybinè praktika pasireiške mažose, uždarose kūrèjų, humanitarinès inteligentijos bendruomenèse, viešosiose miesto erdvèse plačiajai visuomenei (publikai) nebuvo prieinama.

Šiandien besiformuojančių liberalių rinkos santykių prigimtyje glūdi ne ideologinis vienalytiškumas, $o$ „visų esamų ir galimų produkto ar paslaugos pirkejų visuma" (Kotler 2003: 29). O tai reiškia, kad liberalūs kūrejo ir užsakovo santykiai grindžiami abipusiu sutarimu, pasitikejimu menininku kaip „esamų ir galimų produktų " kūreju. Svarbi tampa publika, skirtingi jos kaip kultūrinès paslaugos pirkejjos (vartotojos) norai ir lūkesčiai, t. y. estetinès, etinès vertybès. Jas ugdant svarbus vaidmuo tenka nepriklausomai žiniasklaidai, mene atliekančiai simbolinių vartų vaidmenį ir ugdančiai visuomenès (publikos) tolerantiškumą meninès raiškos ịvairovei.

Tačiau jau $1925 \mathrm{~m}$. ispanų filosofas Jose Ortega y Gasset, žvelgiantis ị naująji meną ne estetiniu, o socialiniu aspektu, straipsnyje „Meno dehumanizacija“ atkreipé dèmesį i tai, kad „<...> naujojo meno masés nepripažįsta, ir taip bus visada. Jis yra nepopuliarus iš esmès; dar daugiau - jis yra antiliaudiškas. Kiekvienas jo sukurtas darbas automatiškai sukelia publikai įdomu sociologinį efektą. Ji pasidalija ị dvi grupes: prielankių- 
jų mažumą ir priešiškųjų daugumą. (Palikime nuošaly dviprasmišką snobų fauną.). <...> Taigi, man regis, charakteringas naujojo meno bruožas „sociologiniu aspektu“ yra dviejų žmonių klasių susidūrimas: suprantančiųjų naująji meną ir jo nesuprantančiųjų. <...> kai žmogui nepatinka meno kūrinys, bet jis supranta ji, žmogus jaučiasi viršesnis už ji ir nepasitenkinimas nekyla. Tačiau, kai darbas nepatinka dèl to, kad jis nèra suprantamas, žmogus jaučiasi ižeistas, pažemintas ir stengiasi tai kompensuoti nepasitenkinimu ir piktumu, $<\ldots>$ prisiminkime, kad kiekvienoje epochoje, kurioje egzistavo dviejų rūšių menas: mažumos ir daugumos, pastarasis visada buvo realistinis" (Ortega y Gasset 1999: 473-487). Aptariamu atveju tai sietina su aplinkoje pasireiškiančiu prieraišumu senoms (tradicinems) normoms ir nepatiklumu naujai meno raiškai.

\section{Naujos nepriklausomos Lietuvos meno lauko PEST'as}

Vertybiniu požiūriu Lietuva yra vèluojančios modernizacijos fenomenas. XX a. tarpukariu prasidejusius sinchronizacijos su to meto Vakarų Europos modernizacija procesus pažeidusi sovietinè okupacija pusei amžiaus dirbtinai sustabde šią raidą. $\mathrm{O}$, ,...> dabar per istoriškai labai jau trumpą laikotarpi jai tenka patirti tokias socialines ir politines įtampas, kokios Europos ir Amerikos civilizaciniuose procesuose buvo „išdalintos" ilgiems istorijos periodams" (Donskis 1993: 114-121). Todèl dabartiniu metu mūsų visuomenèje sąveikauja viena kitą neigiančios vertybinès nuostatos: gręžimosi ị ideologiškai reglamentuostą praeitị, neigiamo požiūrio ị dabarties modernizaciją ir dinamiškos kaitos bei atsinaujinimo, veiklios kasdienybès vertinimo.

Politinèje erdvèje vyko (vyksta) perèjimas nuo vienpartinès, ideologiškai reglamentuotos, link demokratiškų, skirtingų politinių pažiūrų kūrybos bei išraiškos laisvès ir įvairovès ịteisinimo. Valstybe išlieka pagrindine kultūros raidos donore. Todèl stambiụ ekonominių investicijų reikalaujantys užsakymai viešosiose miesto erdvėse atsidūrè naujų politikų rankose. O tiek senoji, tiek naujoji politinè nomenklatūra meno objektus viešosiose miesto erdvèse tebesieja su politinio įvaizdžio ir galios reprezentavimo priemone (pvz.: a. a. prezidento, socialdemokratų lyderio Algirdo Brazausko inicijuotas Valdovų rūmų, Artūro Zuoko Ermitažo ir Gugenheimo muziejaus, „Fluxus ministerijos" projektai).

Ūkio restruktūrizacija vyko (vyksta) skatinant ne smulkųji ir vidutinị, o politikų remiamą stambųjį, monopolistinị (korporatyvnį) kapitalizmą. Pamažu atsinaujinantis valstybinis ir visuomeninis kultūros sektorius, iš lèto besiformuojantis privačių kultūros isstaigų tinklas stabdo alternatyvių, ne valstybinių užsakymų viešosiose miesto erdvėse atsiradimą.

Panaikinus politinę cenzūrą, svarbus vaid muo formuojant naujas visuomenès vertybes teko nepriklausomai žiniasklaidai, ketvirtajai valdžiai. Tačiau plètojantis rinkos santykiams, palaipsniui nykstant nepelningai analitinei, nišinei ir kultūrinei žiniasklaidai bei isitvirtinant (dominuojant) komercinei bulvarinei užsakomajai, žiniasklaida tampa ne kritinio analitinio požiūrio ugdymo, o supriešinančio visuomenę politinio populizmo, populiariosios kultūros, skandalų bei raganų medžioklių tribūna.

Ekonominèje erdvėje sparti paslaugų sektoriaus plètra (Maxima - apie viska pagalvota!) formuoja naujus vartotojiškus podeficitinès visuomenès poreikius bei įpročius. Apsipirkimas prekybos centruose, nuolaidų, laimingos valandos magija keičia visuomenès ipročius. Didieji prekybos ir pramogų centrai tapo paklausiausiais naujosios Lietuvos svajoniu fabrikais. Kas penktam šalies gyventojui gyvenant žemiau skurdo ribos apsilankymas žiemą šiltuose, vasarą gaiviuose, erdviuose, prekybos centruose yra galimybè ne tik apsipirkti, bet ir praleisti laisvalaikị, pramogauti.

Sociokultūrinėje erdvèje aplinka keitėsi greičiau, nei ị gausų prekių ir paslaugų vartojimą įsitraukusiems podeficitinès visuomenès nariams kilo poreikis analizuoti, kritiškai vertinti vykstančius procesus. Viena to priežastis - Lietuvoje nestiprios visuomeninio aktyvumo tradicijos. Mat istoriškai Lietuvoje ilgai galiojo vertikalūs ryšiai - „pono ir baudžiauninko. <...> Lietuviai buvo valstiečiai, o pilietinè visuomenè - labiau miesto negu kaimo savybè. Visuomeninis gyvenimo pagyvéjimas, prasidejęs pirmosios nepriklausomybès metais, sovietmečiu vèl buvo vertikalizuotas. Žmogus (menininkas - E. L.) bendraudavo su valdininku (užsakovu E. L.) lyg mužikas prašydamas malonès, o ne kaip pilietis, reikalaujantis, kad jo teisès būtų gerbiamos. <...> Tad antrojo tautinio atgimimo sulauke $<\ldots>$ tauta $<\ldots>$ beveik be visuomeninio kapitalo ir pilietinio solidarumo“" (Girnius 1999: 589). Išsilaisvinusi tauta išsiskaidè, jos piliečiai susikoncentravo ị individualių tikslų siekimą. Sparčių pokyčių aplinkoje visuomenè susiskirstẻ $\mathfrak{z}$ atsinaujinimo ir tradicinių vertybių šalininkus. Aplinkoje, kaip pastebejo Jose Ortega y Gasset, kilo itampa tarp atviros permainoms, nukreiptos į ateitị, suprantančios, toleruojančios naująji meną mažumos bei romantizuojančios praeitị, tradiciní, realistinị meną išpažǐstančios visuomenès daugumos. Tokia laikysena sietina su kultūros politikos tautos emancipacijos modeliu, „kuris būdingas buvusioms kolonijoms bei taikomas daugelyje posovietinių Rytų Europos šalių [tarp jų ir Lietuvoje - E. L.]. Jo pagrindinis bruožas - naci- 
onalinių kultūros tradicijų, užgniaužtų kolonizacijos ar okupacijos, îtvirtinimas ir plètra. Tai neretai skatina kultūros „uždarumą“ ir nacionalizmą, netgi šovinizmą, kai atmetamas visas okupacinio laikotarpio menas, ignoruojama mažumų kultūra, taip pat jau egzistuojantis ar atsirandantis šalyje alternatyvus, eksperimentinis menas. Daugelyje tokių šalių susiklosto priešprieša tarp europietiškai orientuotos mažumos (nacionalinio elito) ir tradicinès kultūros terpëje gyvenančių gyventojų daugumos: kyla naujų konfliktų tarp elitinio kultūros modelio, orientuoto į universalias kultūros vertybes, ir populistinio modelio, orientuoto ị nacionalines vertybes <... >“ (Dragisevič-Šešič 1998: 16).

Technologinėje erdvẻje augančios gamtinių ir energetinių išteklių, statybos medžiagų ir paslaugų kainos mažina grynųju skulptorių skaičių. Informacinių technologijų plètra lèmé naujų medijų meno atsiradimą. Jos keičia kūrèjo ir publikos komunikacijos būdus ir ịpročius. Virtualioms socialinių tinklų bendruomenèms susiburti jau nebereikia viešosios miesto erdvès. Postmodernistineje poindustrinëje žinių visuomeneje auga kūrybingumo, išraiškos laisvès bei ịvairoves paklausa.

\section{Naujos nepriklausomos Lietuvos meno viešosiose erdvėse kūrèjų, užsakovų ir publikos vertybiu sandraugos ypatumai}

Dèl vèluojančios modernizacijos nūdienos viešosiose miesto erdvèse vienu metu reiškiasi senosios, posovietinès, ir naujosios, postmodernistinès, kūrybinès praktikos. Menas viešosiose miesto erdvèse vystosi susiduriant (konfliktuojant) tradicinėms (monumentalioji, paminklinè ir dekoratyvinè skulptūra) ir naujoms (konceptualūs, skirti konkrečiai vietai (site specific) skulptiniai objektai ir socialiai angažuota (socially engaged) kūryba, suvienijanti veiksmui kūrèjus ir publiką, t. y. skirtingas socialines grupes (bendruomenes), šios kūrybos ištakos sietinos su XX a. pradžios dadaistų, pokario fluxus sąjūdžio aktyvizmu) meninėms programoms bei vertybinèms nuostatoms.

Filosofas Frederic Jameson atkreipia dèmesį, kad naujų vertybių, susijusių su pasaulèžiūra, požiūriu postmodernizmas „,...> turi susieti iškilusius naujus formalius kultūros bruožus su naujo pobūdžio visuomeniniu gyvenimu ir nauja ekonomine tvarka - tai dažnai eufemistiškai vadinama modernizacija, postindustrine ar vartotojiška visuomene, žiniasklaidos ar fasadine visuomene ar tarptautiniu korporatyviniu kapitalizmu“. Aptardamas meninę reiškinio kaitą filosofas pažymi, kad „<...> didžiuma postmodernizmo kūrinių kyla kaip specifinè reakcija ị ̨̧sitvirtinusias klasikinio modernizmo formas, ị vienokị ar kitokị vyraujantị gryną mo- dernizmą, užkariavusị universitetus, muziejus, meno galerijas ir fondus. Tie senesni griaunantys ir maištingi stiliai - abstraktus ekspresionizmas $\langle\ldots\rangle$ - kuriuos mūsų seneliai laike skandalingais ir šokiruojančiais, kartai, atsidūrusiai prie septintojo dešimtmečio (kaip ir XX-XXI amžių sandūros Lietuvoje - E. L.) slenksčio, atrodè nusistoveję ir priešiški - negyvi, sustingę, kanoniški, sumaterialèję monumentai, kuriuos reikia sugriauti, kad nuveikt ką nors nauja. Tai reiškia, kad skirtingų postmodernizmo formų bus tiek, kiek anuomet buvo klasikinio modernizmo formų, nes pirmosios yra bent jau iš pradžių specifinès ir paplitusios reakcijos i̇ antrųjų modelius" (Jameson 1983-1998: 1).

Tai svarbu, nes skatina ieškoti nūdienos sąsajų ne tik su Vakarų, bet ir sovietinių metų kūrybinemis praktikomis, kurios jau anuomet vertybiniu požiūriu nebuvo vienalytès. Vertybiniu požiūriu sovietinių metų meno viešųjų miesto erdvių raidoje ryškios trys kryptys: tradicinè, modernistinè, postmodernistinė.

Pirmoji - ideologiškai reglamentuota tradicinè paminklinè skulptūra. Lietuvoje, jau prasidejus Atgimimo Sąjūdžiui, vis dar tebevykdomas lenininis monumentaliosios propagandos planas, kurio tikslas buvo kiekviename mieste pastatyti vado paminklą, 1988 m. paskelbtas Lenino paminklo konkursas Kapsuke (dabartinèje Marijampoleje).

Antroji - Vakarų modernizmo klasikų Jacques Lipchitz, Jacob Epstein, Henry Motore ịkvèptų modernizuotų monumentaliosios (paminklinès) ir dekoratyvinès plastikos kūrinių atsiradimas viešosiose miesto erdvėse. Jị lèmé per chruščiovinị atšilima kilęs politinių ideologų siekis atminties ženklams suteikti šiuolaikinę formą (Alfonsas Ambraziūnas - Kauno IX forto memorialo paminklas, $1984 \mathrm{~m}$., architektai Gediminas Baravykas, Vytautas Vielius, paminklas yra Kaune; Steponas Šarapovas - Paminklas tarybinès armijos kariams, žuvusiems koncentracijos stovykloje „Oflager 53“, 1977 m., architektas Gediminas Baravykas, paminklas yra Pagégiuose; ir kt.). Aptariant anuometinius, dažnai konformistinius menininko ir užsakovo santykius, įdomi modernaus M. K. Čiurlionio paminklo Druskininkuose (1975 m., skulptorius Vladas Vildžiūnas, architektas Rimantas Dičius, 1 pav.) istorija. Šiame paminkle, kuris oficialiai buvo pastatytas kaip biustas, panaudotos raiškos priemonès, naikinančios ribą tarp figūros ir postamento, leidžiančios sukurti šiuolaikiškai traktuotą kompoziciją. Tiesa, pritarimas tokiam sprendimui radosi tik po ilgų menininko diskusijų su tuometiniu Lietuvos SSR kultūros ministru Lionginu Šepečiu.

Lygiagrečiai 7-8 dešimtmečiuose pasireiškusị dekoratyvinès skulptūros atsinaujinimą lèmè atšilimo modernizacijos procesai bei sovietiniais metais kaip 


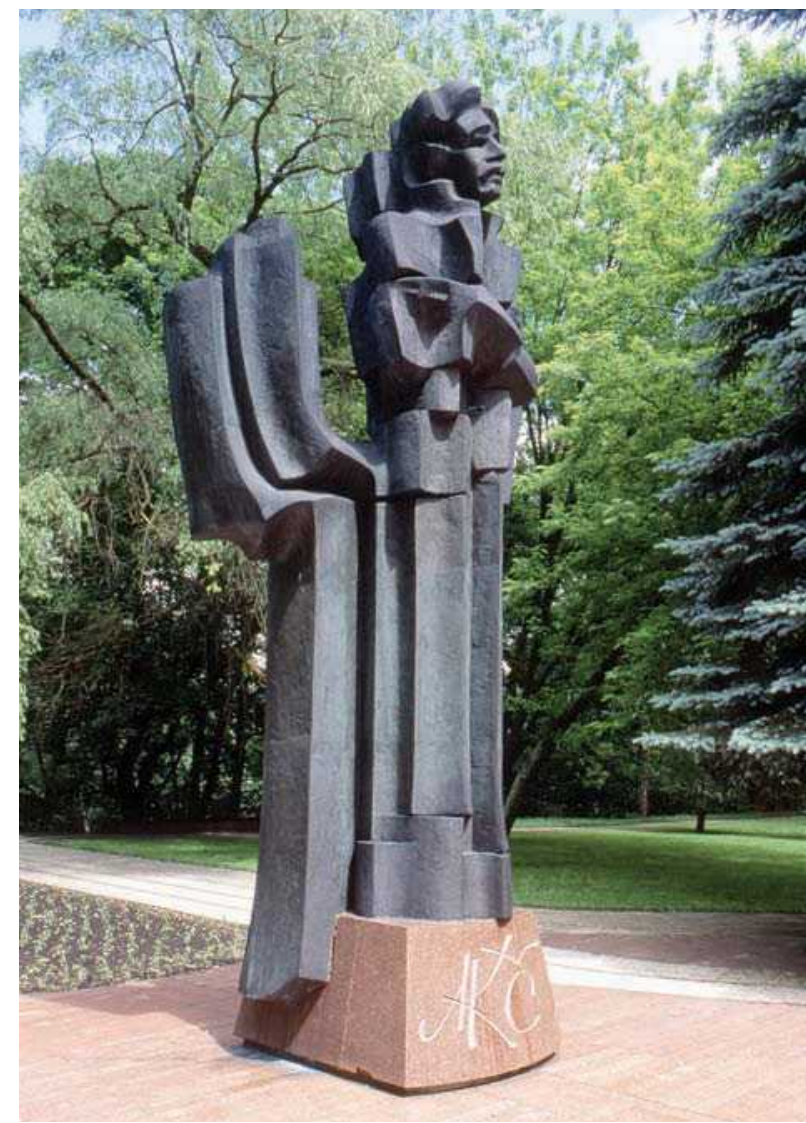

1 pav. Paminklas M. K. Čiurlioniui, autorius Vladas Vildžiūnas, Druskininkai, 1975 m., archit. Rimantas Dičius

Fig. 1. M. K. Čiurlionis Monument, author Vladas Vildžiūnas, Druskininkai, 1975, arch. Rimantas Dičius

ir kitose šalyse (Vokietijoje, Švedijoje ir kt.) galiojęs nutarimas, kad statant naujus visuomeninius pastatus 2 proc. sąmatinès vertès turi būti skiriama puošybai, t. y. ir viešosioms erdvèms sutvarkyti. Tai skatino modernizmo principus išpažistančiu architektų ir skulptoriu bendradarbiavimą bei plète dekoratyvinès skulptūros raiškos ribas (Teodoro Kazimiero Valaičio „Vètrunge““ (1973 m., architektas Vytautas Čekanauskas, 2 pav.), Gedimino Karaliaus „Rytas“ (1975 m., architektas Kęstutis Šilgalis) Lazdynų mikrorajone Vilniuje, taip pat „Skrydis“ (1975-1977 m., architektas Algimantas Sprindys) Druskininkuose arba „Dekoratyvinis fontanas“ (1988 m.) Vilniuje, prie anuometinio Lietuvos SSR Aukščiausiosios Tarybos pastato (architektai Algimantas ir Vytautas Nasvyčiai ir kt.)).

Trečioji - pavieniai vietinio postmodernizmo požymiai, plečiantys dekoratyvinès skulptūros sampratą viešosiose miesto erdvèse. Naująji postmodernistini Mykolo Žilinsko galerijos pastatą vainikuoja Petro Mazūro skulptūra „Žmogus“ (1986 m., architektas Eugenijus Miliūnas, Kaunas), savo konceptualizuo-

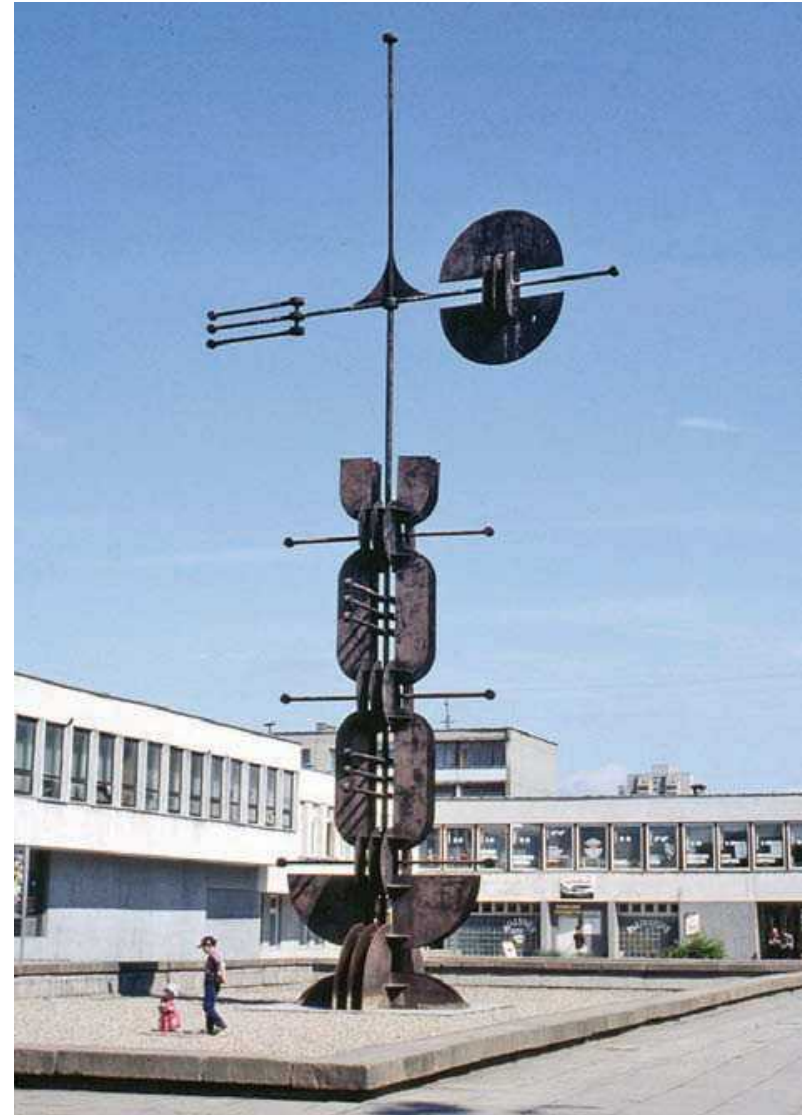

2 pav. Vètrungè, autorius Teodoras Kazimieras Valaitis, Lazdynai, Vilnius, 1973 m., archit. Vytautas Čekanauskas

Fig. 2. Weathercock author Teodoras Kazimieras Valaitis, Lazdynai district, Vilnius, 1973, arch. Vytautas Čekanauskas

tu kūniškumo atvirumu anuomet ir šiandien tebekelianti konservatyviųjų laikinosios sostinès gyventojų, kaskart reikalaujančių miesto vadovus nukelti ją, pasipiktinimą.

Lygiagrečiai viešosiose miesto erdvèse pradedamos rengti laikinos konkrečiai vietai skirtos (site specific) skulptūrinių objektų ekspozicijos. Pirmoji iš jų - Mindaugo Navako betoninių „Išklotinių“ ir Gintauto Trimako bei Alvydo Lukio fotografiju paroda Aliumnato kiemelyje Vilniuje, surengta $1987 \mathrm{~m}$. (3 pav.). Menininkų bendraminčių susibūrimuose, viešosiose privačiose erdvése rengiamos meninès akcijos (Kazès Zimblytès instaliacijos iš ryžių popieriaus sode prie skulptorių dirbtuvių Jeruzaleje, Vilniuje (1978 m.), Briedžiūnų vienkiemyje (1979 m.), Petro Mazūro skulptūrinis objektas „Pripūstas“ sode prie skulptorių dirbtuvių Jeruzaleje (1978 m., 4 pav.)). Postmodernizmo požiūriu paminètini Mindaugo Navako pirmojo „Vilniaus sąsiuvinio“ (1981-1986 m., 5 pav.) „cinkografijos - fotomontažai, kuriose jo skulptūros derinamos su didžiuliais pastatais, šokiruojančiais žiūrovą formų sugretinimo paradoksalumu, mastelio žaisme, <...> 


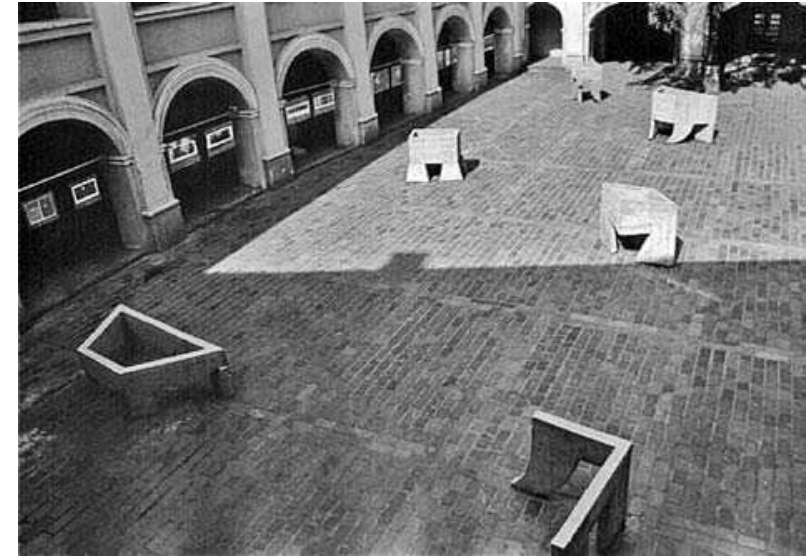

3 pav. Mindaugo Navako betoninių „Išklotiniu“", Gintauto Trimako ir Alvydo Lukio fotografijų paroda, Aliumnato kiemelis, Vilnius, $1987 \mathrm{~m}$.

Fig. 3. Exhibition of Mindaugas Navakas Concrete "slabs" along with the photographs by Gintautas Trimakas and Alvydas Lukys, Alumnatas Courtyard, Vilnius, 1987

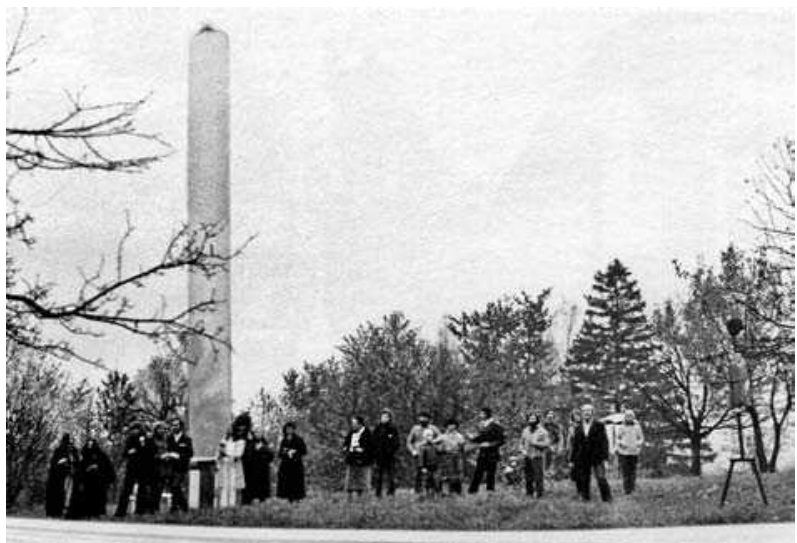

4 pav. Skulptūrinis objektas "Pripūstas" sode prie skulptorių dirbtuvių Jeruzaleje, Vilniuje, autorius Petras Mazūras, $1978 \mathrm{~m}$.

Fig. 4. Plastic object The Inflated in the garden at the sculptors' atelier in Jeruzalè, Vilnius, author Petras Mazūras, 1978

skatina permąstyti gerai žinomas skulptūros mieste funkcijas: erdvę organizuojantis idejinis orientyras (paminklas), standartinę architektūrą gaivinantis papuošalas (dekoratyvioji skulptūra)“(Kreivytė 1997: 35).

Prisimenant vèlyvųjų sovietinių metų kūrèjų ir politikos sankirtas, dera pamineti, kad Atgimimo Sąjūdis kilo ir kristalizavosi humanitarinès inteligentijos, menininkų aplinkoje, o vienas jo ideologinių lyderiu - profesorius Vytautas Landsbergis - bei fluxus sąjūdžio pradininkas Jurgis Mačiūnas buvo klasès ir kiemo draugai, kurių ryšiai, pastarajam emigravus $\mathfrak{i}$ $\mathrm{JAV}$, atsinaujino 7-ajame dešimtmetyje ir virto susirašinèjimu, paskatinusiu būsimą profesorių $1966 \mathrm{~m}$.

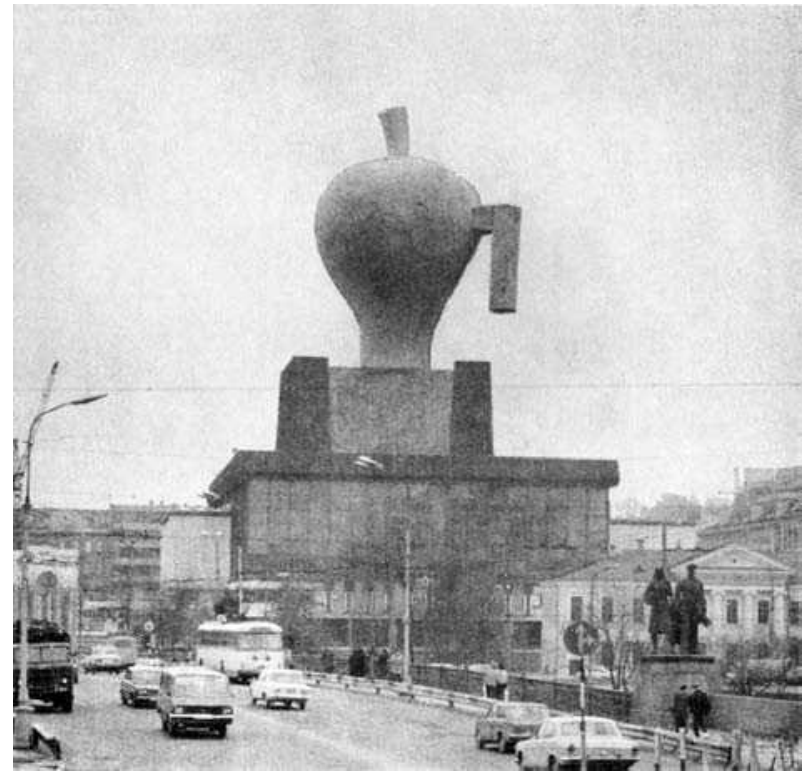

5 pav. Vilniaus sąsiuvinis I, 1981-1986 m., autorius Mindaugas Navakas

Fig. 5. Vilnius Notebook 1, 1981-1986, author Mindaugas Navakas

Vilniaus Pedagoginiame institute surengti pirmąji viešą Fluxus koncertą. Socialinio aktyvizmo ir sąryšio su fluxus sąjūdžiu požymių galima apčiuopti ir $1989 \mathrm{~m}$. rugpjūčio 23 d., kai Ribentropo-Molotovo pakto paminejjimo pilietinejje Baltijos kelio akcijoje už rankų susikibę Lietuvos, Latvijos ir Estijos piliečiai sudare gyvą 600 kilometrų apie 2 milijonų žmonių grandinę nuo Vilniaus iki Talino.

1988 m. susiburia fluxus sąjūdžio socialinio aktyvizmo įkvèpta jaunųjų menininkų grupe „Žalias lapas“ (Gediminas Urbonas, Džiugas Katinas, Artūras Makštutis, Julius Liudavičius, kompozitorius Gintaras Sodeika), kuri „deklaravo ieškanti netradicinių išraiškos priemonių, siekianti meno šakų ir žanrų suartinimo ir kontakto su žiūrovais. Taip $1990 \mathrm{~m}$. gruodžio $10 \mathrm{~d}$. Tarptautinès žmogaus teisių gynimo dienos proga Vilniaus Rotušèje surengta akcija „Kelias“ (6 pav.) - ant asfalto iš suodžių ir kreidos suformuotus žmonių figūrų siluetus sunaikino ir išsklaide po aplinkines gatves pravažiuojančių automobilių ratai“ (Kreivytè 1997: 36).

Tuokart viešųjų Sąjūdžio mitingų bei dainuojančios revoliucijos siekių suvienyti politikai, visuomenè (publika), miesto kiemsargiai tolerantiškai reagavo ị senamiesčio gatves, miestiečių apavą ir aprangą padengusias suodžių mikrodaleles. O praejjus porai dešimtmečių nuo tada, kai buvo atkurta nepriklausomybé, monopolistiniams rinkos santykiams vis labiau įsigalint, ekonominès krizès akivaizdoje stiprejjant socialinèms įtampoms, visuomenès nesaugumui, $2009 \mathrm{~m}$. vasario $13 \mathrm{~d}$. Neries krantinèje Vilniuje iškilus sukons- 


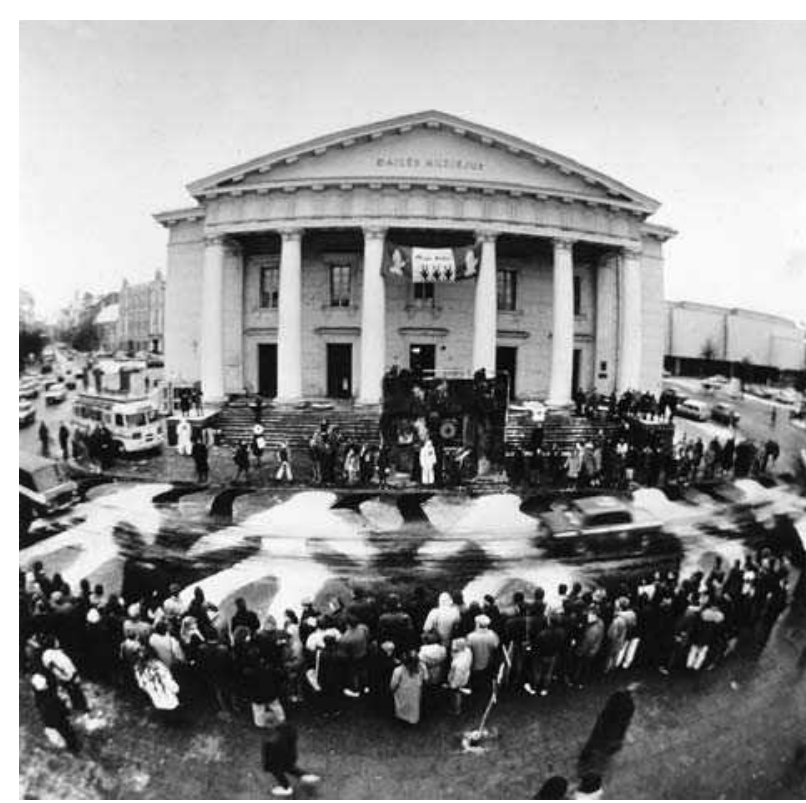

6 pav. „Žalio lapo“ grupès akcija „Kelias" priešais Lietuvos dailès muziejaus centrinius rūmus, Vilnius, 1990 m. gruodžio $10 \mathrm{~d}$.

Fig. 6. Action Road by the group Green Leaf („Žalias lapas“) in front of the central building of the Lithuanian National Art Museum, Vilnius, 10 December, 1990

truotai iš demontuotų Rusijos „Družbos“ dujotiekių vamzdžių Vlado Urbanavičiaus „Krantinès arkai“ (VEKS 2009 viešuju erdvių humanizavimo programos kūriniui, kiti Neries krantinès skulptūru projekto darbai - Mindaugo Navako „Dviaukštis“, Roberto Antinio „Puskalnis“), îsiplieskè sutapęs su spaudimu VEKS 2009 projektui politikų ir žiniasklaidos ižžiebtas šaltasis karas, supriešinęs meninę bendruomenę bei publiką i projekto mėgèjus (pirmas šiuolaikinio meno kūrinio interneto dienoraštis Lietuvoje (http:// vamzdis.blogas.lt), Šnipiškių seniūnijos 2009 m. naujametinis sveikinimas, 7 pav.; ir kt.) bei jo priešininkus (2009 m. kovo $16 \mathrm{~d}$. ant skulptūros pakibęs pakaruoklis Feliksas ir kt.).

Šių ittampų priežastys susijusios su nepriklausomybẻs laikotarpio vertybinių kūrèjo, užsakovo ir publikos sandraugos modelių kaita, tiksliau vertybine senų (posovietinių) ir naujų (liberalių) modelių, pasireiškiančių pavieniui (naujosios kairés, mokymosi iš Las Vegaso, politines apropriacijos), prieštara.

Posovietinis modelis paremtas autokratine politine valdžia, primetančia savo valią ir galią menininkui.

„Dar Senovès Romoje buvo priimtas ístatymas Damnatio memori („Atminties prakeikimas“), pagal kurị privalu naikinti statulas, reljefus arba įrašus, kažkada sukurtus smerkiamo asmens šlovei. Tai reikalinga daryti tam, kad pasmerktojo vardas, jo išvaizda būtų ištrinti iš ateinančiųjų kartų atminties" (Jankevičiūtè

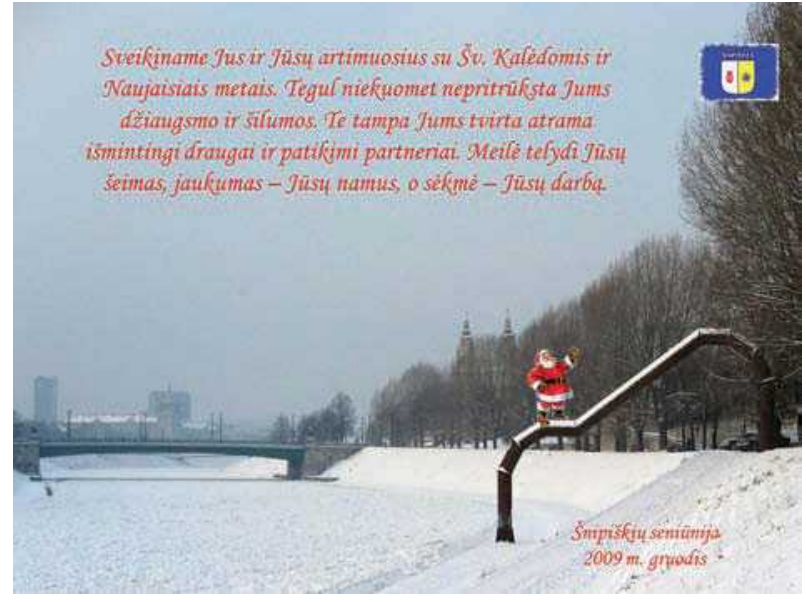

7 pav. „Krantinès arka“, autorius Vladas Urbanavičius, Vilnius, 2009 m., Šnipiškių seniūnijos 2009 m. gruodžio mèn. naujametinis sveikinimas

Fig. 7. Quay Arch, author Vladas Urbanavičius, Vilnius, 2009, New Year greeting to Šnipiškès district Housing Council, December 2009

1992: 58). Atkūrus Lietuvos nepriklausomybę suskubta keisti senosios sistemos ženklus. 1989-1993 m. Lietuvoje buvo demontuotos 42 tarybinio laikotarpio paminklinès skulptūros, kurios nuo $2000 \mathrm{~m}$. eksponuojamos privačiame Grūto parko sovietinių metų skulptūrų muziejuje. Panaikinus senosios politinès sistemos ženklus, suskubta atstatyti sovietmečiu nugriautus paminklus bei nukeltųjų vietoje kurti naujus. Tačiau jiems kurti pasitelktos senos meninès ir organizacinès priemonès, todèl jie primena uniformas pakeitusias Grūto parke besiilsinčias sovietmečio statulas. Naujųjų paminklų statybą inicijuoja politikai, rečiau bendruomenès, didelių valstybès subsidijų reikalaujantis sprendimų prièmimas tęsiasi kelis metus (pvz., Lukiškių aikštès sutvarkymo 2008, 2009, 2010 m. konkursai). Rengiamas ir skelbiamas viešas konkursas, dažniausiai keli jo turai, kuriuose pristatomus projektus vertina išplèstinė meno ekspertų ir visuomenès atstovų komisija, kuri priimdama kolektyvinius sprendimus, vengdama viešų konfliktų, siekia išreikšti konservatyvias tradicines didžiosios daugumos, nuosaikaus realizmo stilistikos vertybes. ${ }^{1}$ Šiame metų metais besitęsiančiame procese skirtinguose paminklų konkursuose galima aptikti menkai pakitusius senųjų konkursų

\footnotetext{
1 Pirmame „Vilniaus ịkūrimo“ paminklų projektų konkurse (1988 m.) premijuotus septynis Regimanto Midvikio, Gedimino Karaliaus, Stanislovo Kuzmos, Mindaugo Navako, Petro Repšio, Sauliaus Šiukštos, Vlado Urbanavičiaus projektus nurungè nuosaikus Vytauto Kašūbos projektas), „Atsisveikinimo su Lietuva“ (1989 m.) užsakovai atmete žiuri geriausiai ịvertintą Mindaugo Navako monumentalų kryžių bei pirmenybę atidavẻ lyriškesniam Vidmanto Gylikio projektui.
} 
projektus. Taip šiandien Vilnių puošiantis Regimanto Midvikio paminklas Mindaugui (2003 m., architektai Ričardas Krištopavičius, Algimantas Nasvytis, 8 pav.) yra „Vilniaus ịkūrimo“ bei „Gedimino paminklo“konkursuose pristaty to projekto perdirbinys.

Dèl posovietinio požiūrio naujuose nūdienos paminkluose dominuoja sovietiniais metais diegti iš monarchizmo epochos perimti monumentaliosios propagandos kanonai, kai atminties ženklai siejami su tradiciniais pagarbos ir pagerbimo ritualais, ikalinusiais mūsų šalies politikus, $\mathfrak{i}$ konkursų maratoną ìsijungusius kūrèjus bei politinių sprendimų galia pasitikinčius piliečius. Čia galioja aukos ir budelio sindromas, kai laisvę iškovojęs pavergtasis be išlygų perima engusiojo metodus. Nuvertus vieną stabą, skubama ji pakeisti kitu. Tarsi naujo simbolio atsiradimas senojo vietoje padès nugalèti ar ịveikti buvusị ir esamą nesaugumą. Dėsninga, kad tokioje aplinkoje atsirandantys netradiciniai, šiuolaikiški atminties jamžinimo pavyzdžiai kelia didžiosios daugumos visuomenès (publikos) nepasitenkinimą. Taip „grupe kauniečių karštai protestuoja prieš Roberto Antinio sukurtą ir Nacionaline premija apdovanotą paminklą Romui Kalantai [„Aukos laukas“, 2002 m., architektas S. Juškys - E. L.]. Aktyvistai reikalauja ji jei ne demontuoti, tai bent jau „perdirbti ị vertikalų“. Iniciatyvinès grupes narius piktina ir tai, kad paminklo liepsnos liežuviai neva nukreipti netoli esančių viešųjų tualetų link. Skundai ir protestai adresuojami ne tik savivaldybei, kurios užsakymu paminklas pastatytas, bet ir valstybès vadovams. Gal šis pavyzdys ir labai radikalus,

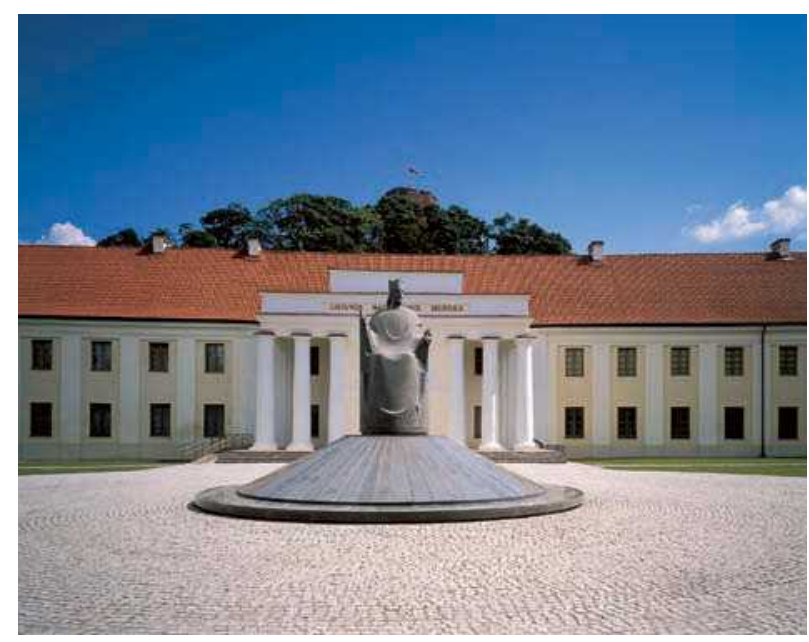

8 pav. Paminklas Mindaugui, autorius Regimantas Midvikis, Vilnius, 2003 m., architektai Ričardas Krištopavičius, Algimantas Nasvytis

Fig. 8. Mindaugas Monument, author Regimantas Midvikis, Vilnius, 2003, architects Ričardas Krištopavičius and Algimantas Nasvytis bet jis liudija, kad be menininkų esama ir kitų grupių, kurioms rūpi paminklai. Tų grupių požiūriai ir nuomonès taip pat daro įtaką paminklų užsakovams“ (Trilupaitytè 2005: 1).

Liberalus modelis paremtas privataus užsakovo ir kūrèjo sutarimu bei pasitikèjimu skulptoriumi. Taigi skirtingų skonių užsakovai turi galimybę neįsitraukdami ị užsitęsiančius ir bevaisius konkursus iš karto pasirinkti jiems patikusius menininkus, o tai užtikrina aplinkoje meninės raiškos įvairovę, t. y. sudaro galimybę išreikšti skirtingus visuomenès (publikos) skonius.

Jo (modelio) ištakos - anksčiau aptartos privačios vèlyvųjų sovietinių metų menininkų iniciatyvos ${ }^{2}$. Stebėdami privačia iniciatyva sukurtus paminklus bei skulptūrinius objektus viešosiose miesto erdvėse aptinkame skirtingų (senų ir naujų) meninių programų visumą. Pavyzdžiui, tradicinis sprendimas, kai „Naujosios komunikacijos mokykla“ žymiam sovietinių metų skulptoriui Konstantinui Bogdanui pateikè užsakymą sukurti ir pastate Vilniuje pirmą pasaulyje paminklą kompozitoriui ir dainininkui Frankui Zappai (1995 m., architektas Valdas Ozarinskas, 9 pav., paminklo replika $2010 \mathrm{~m}$. atidengta Baltimoreje). Kitas pavyzdys - skirtingų visuomeninių organizacijų atstovų nuosaikiai realistinès raiškos paminklai, užsakyti iš skulptoriaus Romualdo Kvinto: paminklai Romein Gary (2005 m.), Daktarui Cemachui Šabadui Vilniuje (10 pav.), Daneil Dolskiui Kaune (abu 2006 m.), Vytautui Kernagiui Nidoje (2008 m). Dar kitas pavyzdys - Jurgos Ivanauskaitès skvere Vilniuje "apsigyvenęs" išraiškingai apibendrintas granitinis skulptorès Ksenijos Jeroševaitès „Katinas“ (2008 m., architektė Virginija Kurpienè, 11 pav.), sukurtas Jurgos Ivanauskaitès atminimo ir palikimo fondo užsakymu, o greta pagrindinių kūrinio pastatymo rèmejų minima privati įmonè UAB „Lietuvos dujos“. Autore džiaugèsi, kad „,_..> sutvarkyta dar viena Vilniaus erdvé. Man labiausiai patiko ideja, kad Jurgos skvere reikia ne balvono, ne paminklo, o paprasčiausio katino. Vienas malonumas kurti, kai nereikia kažko labai solidaus daryti“ (Žadeikaitè 2009).

\footnotetext{
Svarbus vaidmuo nepriklausomybès pradžioje liberalizuojant meno lauką, kūrejjo ir užsakovo santykius, teko 1993-1999 m. veikusiam Lietuvoje Soroso šiuolaikinio meno centrui, kurio suteikta parama meniniams projektams paskatino laikinų site specific projektu viešosiose miesto erdvėse atsiradimą („Skulptūra senamiestyje“ (1994 m.), „Kasdienybès kalba“ (1995 m., abiejų kuratorius skulptorius Algis Lankelis)) „Užmiršta dabartis“ (1997 m., kuratoriai Algis Lankelis, Audrius Novickas, Paul Rodgers (U.K) ir kt.). Šiame kontekste būtina paminèti, kad pagal daug viešosios kritikos sulaukusią VEKS 2009 programą inicijuoti tarpdisciplininiai menu viešosiose miesto erdvèse projektai („Menas netikètose erdvėse“, „Tebūnie naktis!"), kuriuose konkurso būdu atrinktus laikinus projektus mieste igyvendino skirtingų meno šakų bei stilistinès raiškos kūrejjai, sumažino atotrūkị tarp šiuolaikinio meno raiškos ịvairoves ir publikos vertybinių nuostatų.
} 


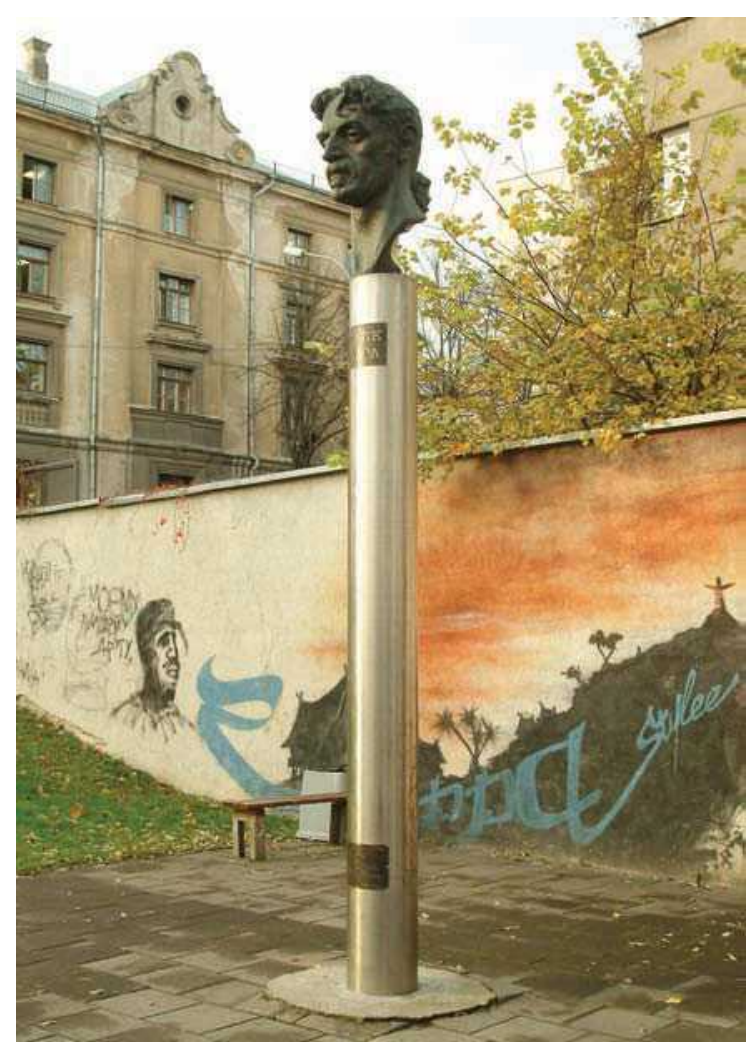

9 pav. Paminklas Frankui Zappai, autorius Konstantinas Bogdanas, Vilnius, 1995 m., archit. Valdas Ozarinskas

Fig. 9. Frank Zappa Monument, author Konstantinas Bogdanas, Vilnius, 1995, arch. Valdas Ozarinskas

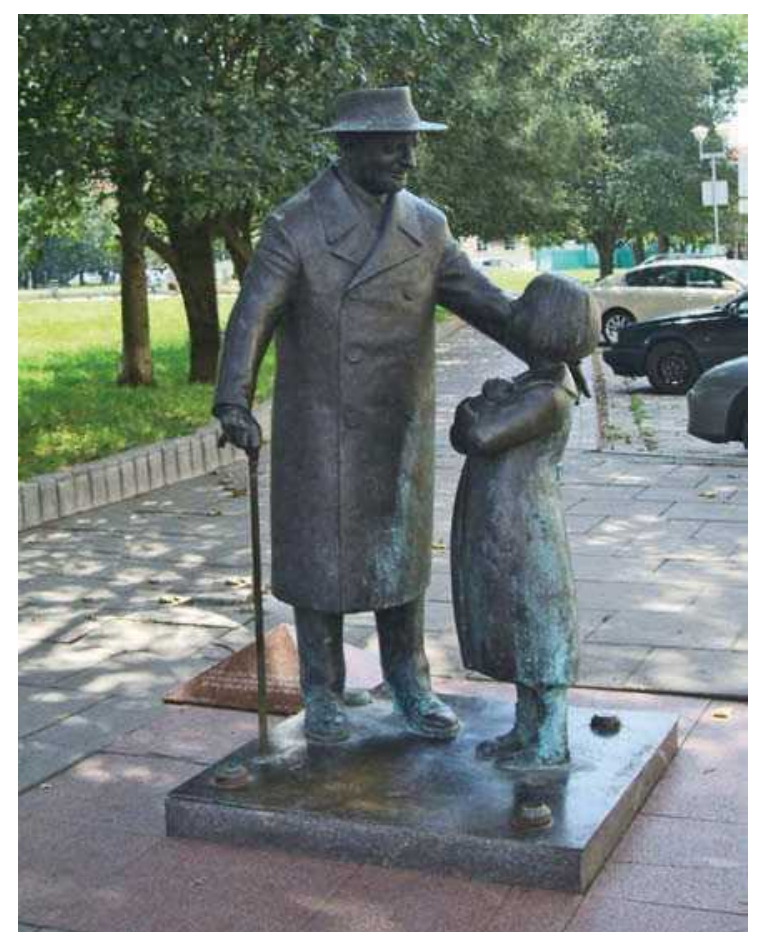

10. pav. Paminklas daktarui Cemachui Šabadui, autorius Romualdas Kvintas, Vilnius, 2006 m.

Fig. 10. Monument to Statue of medical doctor Cemach Szabad, author Romualdas Kvintas, Vilnius, 2006

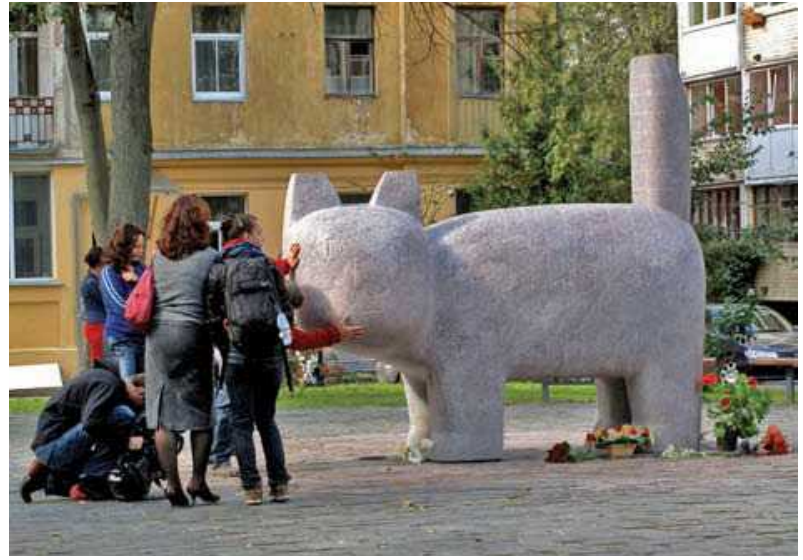

11 pav. „Katinas“, Jurgos Ivanauskaitès skveras, autorè Ksenija Jeroševaitè, Vilnius, 2008 m., architektè Virginija Kurpienè

Fig. 11. Cat, sculpture in Jurga Ivanauskaite Square, author Ksenija Jeroševaitè, Vilnius, 2008, architect Virginija Kurpienè

Kitai site specific skulptūrinių objektų krypčiai priskirtinas „Meno lygos“ užsakymu sukurtas Mindaugo Navako „Kablys“ (1994 m, 12 pav.). Technologiniu požiūriu viena iš ambicingiausių naujųjų laikų skulptūrų - Vlado Urbanavičiaus "Kabantys akmenys“ (2008 m., architektas Linas Tuleikis, konstruktorẻ Jūratė Vašeikienè, projektas „Skulptūrų zona“, Kaunas, 13 pav.). Kūrinio atsiradimą inicijavo privačios Lietuvos ir Vokietijos įmonès Baltic Sign savininkas Vaidotas Skrickas ir „Skulptūrų zonos“ parko kuratorè Rasa Andriušytė-Žukienè. Skulptorius prisipažǐsta, kad ji „Nustebino pagrindinio projekto rèmèjo Vaidoto Skricko noras kuo geriau įvykdyti reikalingus darbus. Tuo jis skyrèsi nuo ịprasto anoniminio užsakovo, vadinamo Valstybe ar bendruomene" (Lubytè 2008: 99).

Ivardinus du pagrindinius, senąji - posovietini - ir naująji - liberalų - kūrèjo, užsakovo ir publikos vertybių sandraugos modelius, reikia aptarti pavieniui pasireiškiančius naujosios kairés, mokymosi iš Las Vegaso, politinés apropriacijos atvejus.

Naujoji kairé. Isibėgèjant monopolistiniams rinkos santykiams, akademinio jaunimo aplinkoje atsiranda požiūris, išreiškiantis maištingas Vakarų kairiųjų politinių pakraipų praktikas (pvz., „Naujoji kairè 95“ - intelektualinis kairiosios pakraipos judejimas). Ieškodami kūrybinio įkvèpimo politinèje, ekonominèje ir socialinëje realybèje, menininkai ịsitraukia ị socialiai angažuotas aktyvumo praktikas. Svarbu pastebèti, kad vertybiniu požiūriu susidomėjusių socialine kritika ir socialiniu aktyvumu kūrejjų priklausymas kairiųjų judejjimui turi kitą prasmę nei tą, kurią suteikia socializmą (sovietų sistemą) praktiškai išgyvenusi vyresniųjų, karta, nepatikliai žvelgianti ị ši sąjūdị. 


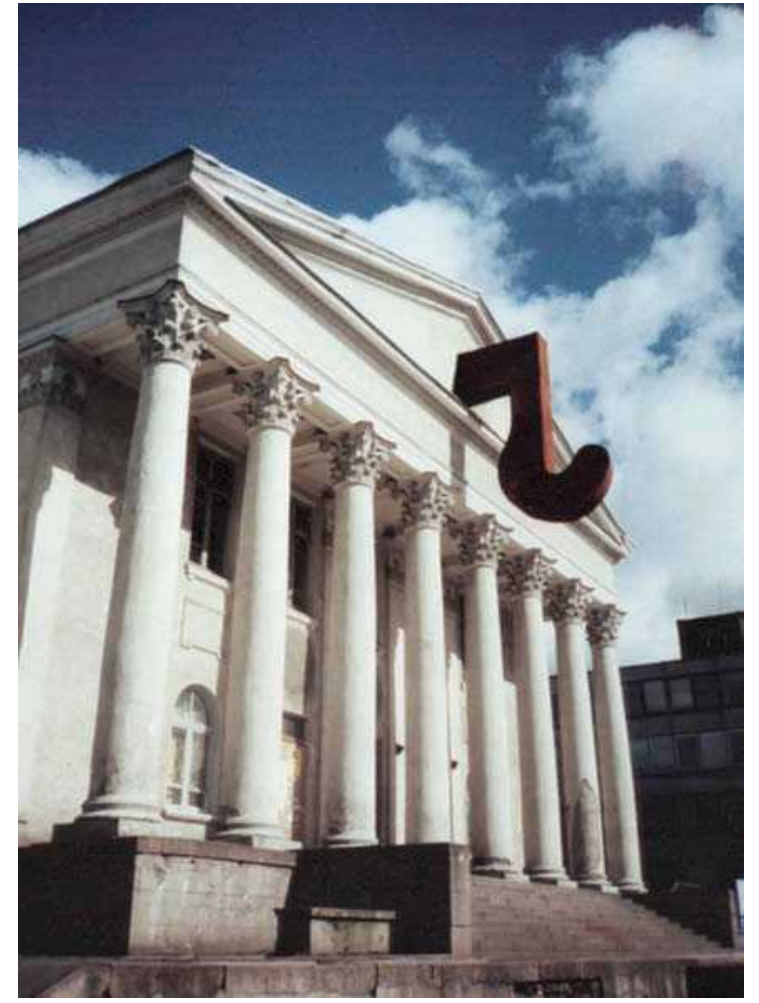

12 pav. Kablys, "Meno lyga“, autorius Mindaugas Navakas, Vilnius, 1994 m.

Fig. 12. Hook, at the Art League "Meno lyga", author Mindaugas Navakas, Vilnius, 1994

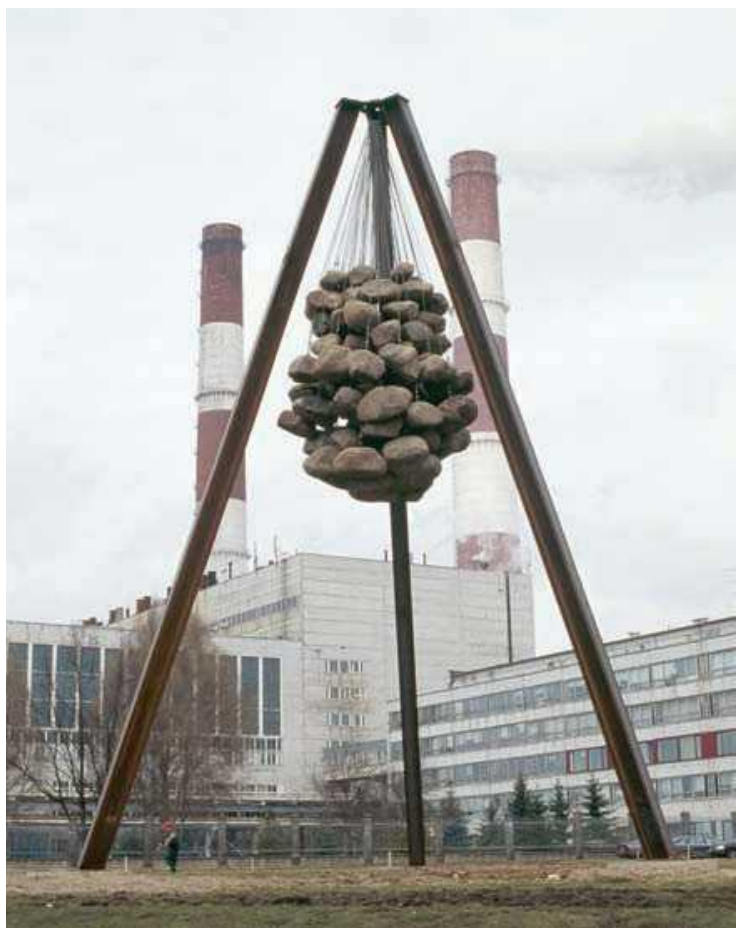

13 pav. Kabantys akmenys, „Skulptūrų zona“, autorius Vladas Urbanavičius, Kaunas, 2008 m.

Fig. 13. Suspended Stones at the Zone of Sculptures („Skulptūrų zona“), author Vladas Urbanavičius, Kaunas, 2008
Šiam sąjūdžiui atstovaujančių Nomedos ir Gedimino Urbonų kūrybiniai projektai tampa komunikacinio akto su visuomene (publika) platforma. Kas kartą keldami naujus tikslus ir uždavinius kūrejjai plečia ne tik savo viešų platformų, bet ir jų dalyvių tinklą (network). Tačiau tai vyksta skirtingai nei politikoje ir ekonomikoje, kur tinklų (JTO, NATO, ES) atsiradimą lèmé bendradarbiavimo poreikis, pagrịstas informacijos sklaida bei tarpininkavimu ir pagalba, siekiant užmegzti naujus ryšius, veikti tarpvalstybinejje aplinkoje, ginti bei atstovauti bendriems interesams. Tačiau Urbonų meninejje praktikoje tinklas tèra komunikacinès vizijos, pozicijos (alternatyvos, iššūkio, protesto) pristatymo priemoné, viešas bendradarbiavimo procesas dažnai tampa svarbesnis už baigtini (pasiektą) rezultatą. Taip tarptautiniam ŠMC organizuotam „Populizmo“ projektui sukurta nauja platforma - „Protesto laboratorija“ (2005 m., 14 pav.), kuri konsoliduodama pilietinę savimonę siekè atkreipti dèmesi i didžiausio ir paskutinio „Lietuvos“ kino teatro privatizaciją, inicijavo pilietinį viešųų erdvių išsaugojimo sąjūdị, naują vertę igijusị visuomenei susidūrus su naujojo monopolistinio verslo ir politikų sandoriais (pvz., LEO LT projektas). Tačiau kas kartą naujai partnerių (sąjungininkų) bendruomenei išreiškiant savo poziciją, plečiant viešų platformų tinklą, menininkai, mesdami iššūki populizmui, atnaujina komunikacinių priemonių arsenalą, inicijuoja pilietinį viešo intereso išsaugojimo sąjūdị, perima bei savo tikslams pradeda naudoti kritikuojamo populizmo metodus - pasitelkę viešųjų ryšių strategijas bendradarbiauja su žiniasklaida, kostiumų dizainere Sandra Striaukaite, kuria ne naują socialiai aktyvią pilietinę platformą, o savo prekių ženklą (angl. brend). Tačiau realybeje išsikeltas projekto tikslas „Laisvę Lietuvai!“, konsolidavęs, ịtraukęs ị ịgyvendinimą plačią auditoriją, liko nepasiektas $^{3}$. Senasis „Lietuvos“ kino teatras, apleistas meno projekto dalyvių, tapo juodąja benamių prieglaudos skyle Vilniaus viešųjų erdvių žemèlapyje.

Mokymasis iš Las Vegaso (pagal JAV postmodernizmo architekto Roberto Venturi knygą Learningfrom Las Vegas) atvejis paremtas mūsų liberalejjančioje podeficitineje visuomenèje stiprejančiais vartotojiškais populiariosios kultūros poreikiais bei populistiniais menininkų siekiais juos patenkinti. Juk „<...> tam tikrų skiriamųjų ribų nutrynimas, akivaizdžiausias senojo skirtumo tarp elito kultūros ir vadinamosios masių ar populiariosios kultūros panaikinimas. Tai turbūt labiausiai pribloškianti aplinkybè akademiniu požiūriu, kuris tradiciškai buvo suinteresuotas apsaugoti grynosios, arba elito, kultūros sritị nuo supančios

3 "Protesto laboratorija“ tapo postūmiu tolesniai kūrybinių bendruomenių konsolidacijai (pvz., 2010-2011 m. Arcitektūros fondo veikla) 


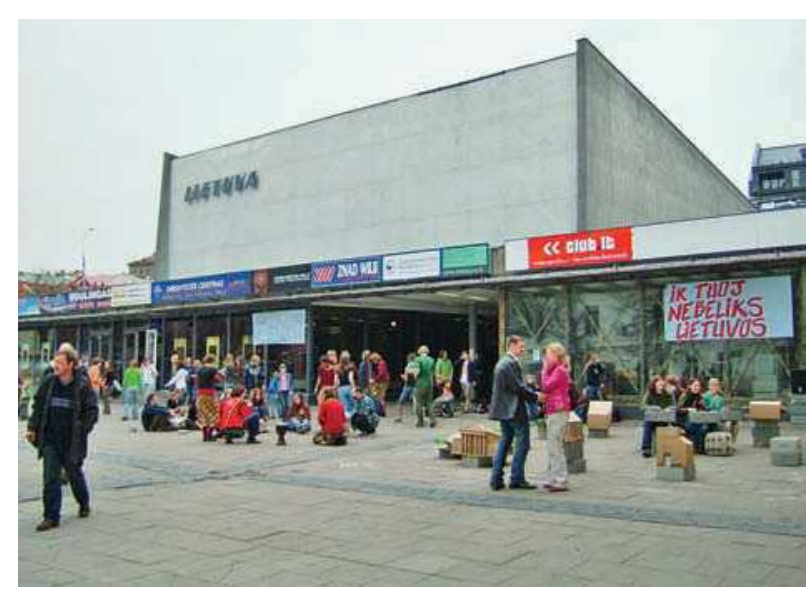

14 pav. „Protesto laboratorija“, kino teatras „Lietuva“, autoriai Gediminas ir Nomeda Urbonai, Vilnius, 2005 m.

Fig. 14. Protest Lab in the cinema "Lietuva", authors Gediminas and Nomeda Urbonas, Vilnius, 2005

miesčioniškos, kičo, TV serialų kultūros ir perteikti naujai priimtiems sunkų ar sudètingą gebejiimą skaityti, klausyti ir regeti“" (Jameson 1983-1998: 1).

Kuriant Baltijos kelio ir Lietuvos nepriklausomybès dvidešimtmečiui skirtą „Laisvès kelio“ paminklą Vilniuje (2010 m., architektas Saulius Pamerneckis), smūgine prekybos agento taktika pasinaudojęs skulptorius Tadas Gutauskas prisipažįsta, kad „Eksperimentinis, avangardinis menas, visa tai įdomu, tačiau greitai iškyla klausimas, kaip gyventi. $<\ldots . .>\mathrm{O}$ tai reiškia, kad meną, kurị darau, reikia pateikti taip, kad jis būtų suvokiamas. Tai nereiškia, kad jis yra ne menas, tiesiog jis turi būti pateikiamas pagal rinkodaros taisykles. <...> yra klaida bandyti pateikti, kad menas ir verslas skirtingi. Juk posakyje „menas yra biznis, o biznis yra menas" yra daug tiesos. Konkurencineje aplinkoje labai svarbios idejos tiek versle, tiek mene. Klaida manyti, kad save galima išreikšti tiktai per kūrinius. Komunikacija čia irgi yra labai svarbu" (Lubyte 2008: 154-155). T. Gutausko pavyzdys yra puikiai igyvendinta viešųjų ryšių akcija, kurios dalyviais tapo 20000 naujosios Lietuvos piliečių, pamiršusių, ką sovietmečiu reiške išgirsti siūlymą pirkti plytą, už asmeninę (vardinę) i paminklą i̇mūrytą plytą sumokèję $25 \mathrm{Lt}$, o už šeimos - 50 Lt. „Savo plytą í skulptūrą turètų įdèti kiekvienas, kuris pasirašo po Lietuvos laisvès ideja!“- taip projektą reklamavo publikos numylètinis Andrius Mamontovas, viešajame TV eteryje jam antrino architektas Algirdas Kaušpèdas, Marijonas Mikutavičius. Siekusiai įamžinti savo laisvès troškimą į memorialinių plytų pirkimo ir išpardavimo akciją ịtrauktai publikai investicijų grąžą tvirtino į paminklo atidarymo ceremoniją susirinkęs Lietuvos politinis elitas (15 pav.). Beda ta, kad projektas, tiksliau - neigyvendinto Lukiškių aikštès „Laisvès“ paminklo projekto

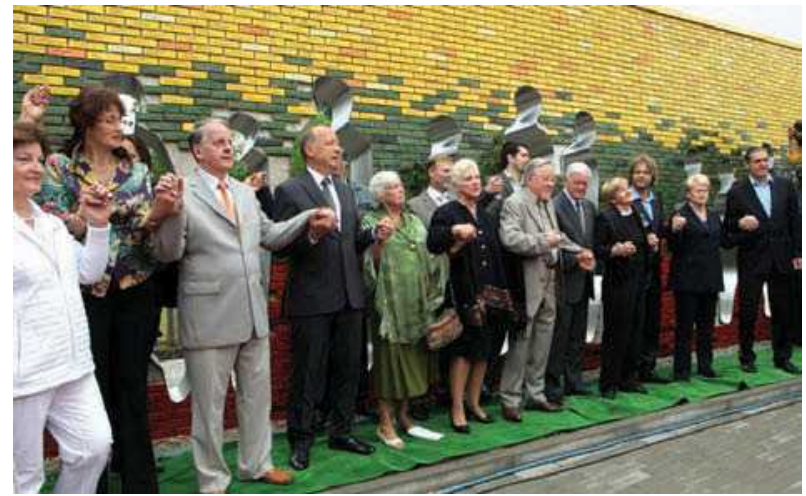

15 pav. Paminklo "Laisvès kelias" atidengimo ceremonija, Vilnius (2010 08 23), skulptorius Tadas Gutauskas, architektas Saulius Pamerneckis

Fig. 15. The opening ceremony of the monument Road of Freedom, Vilnius (23 Aug. 2010), sculptor Tadas Gutauskas, architect Saulius Pamerneckis

(2008-2008 m., architektas Rolandas Palekas) perdirbinys yra plastiniu ir prasminiu požiūriu nepavykęs (prastas) kūrinys. Juk naujosios Lietuvos nepriklausomybès atgavimas siejamas su Berlyno sienos griovimu, o ne naujų sienų statymu!

Politine apropriacija (lot. appropriatio - ko nors užvaldymas, pavertimas savo nuosavybe) pasireiškia politikų siekiu pasitelkti kultūrinius projektus kaip matomumo, populiarumo, t. y. viešo ịvaizdžio kūrimo priemonę. Šiai krypčiai priskirtina Artūro Zuoko fluxus sąjūdžio apropriacija. Pradžioje ji buvo vykdoma inicijuojant Jono Meko vizualiųjų menų centrą, igyjant Jurgio Mačiūno kolekciją, generuojant Ermitažo ir Gugenheimo muziejų filialo Vilniuje projektą. Naujausiame, jau meniniame, socialinio aktyvumo „Fluxus ministerijos“ (16 pav.) projekte politikas pasitelkè populistinę politiko persikūnijimo ị menininką strategiją, pasinaudojo ja kaip paslèptos rinkiminès kampanijos priemone. Liberalų ir centro sąjungos išsinuomotose buvusiose Sveikatos ministerijos patalpose $2010 \mathrm{~m}$. pavasarị jauniesiems menininkams buvo metams suteiktos studijos-dirbtuvès, jos subūrè kūrèjus bei jų publiką socialiai aktyviai kūrybinei veiklai. Perimdamas fluxus sąjūdžio lyderio Jurgio Mačiūno XX a. 7 deš. Niujorko SoHo rajone įsteigto menų kooperatyvo idejją, naujosios ministerijos ministras, palikęs Liberalų ir centro sąjungą ir ịkūręs visuomeninị judèjimą TAIP (Tẻvynès atgimimas ir perspektyva), rengiasi dalyvauti $2011 \mathrm{~m}$. savivaldybių tarybų rinkimuose. Laikinai menu užsiimantis politikas pamiršo (o gal ir nežinojo?!), kad fluxus sąjūdžio pasaulèžiūros vertybès buvo paremtos institucine (taip pat ir ministerijų!) kritika. Panašu, kad menininko portfelis naujosios ministerijos ministrui yra tik naujas gelbèjimosi ratas politinejje kovoje už valdžią. O koks jame 


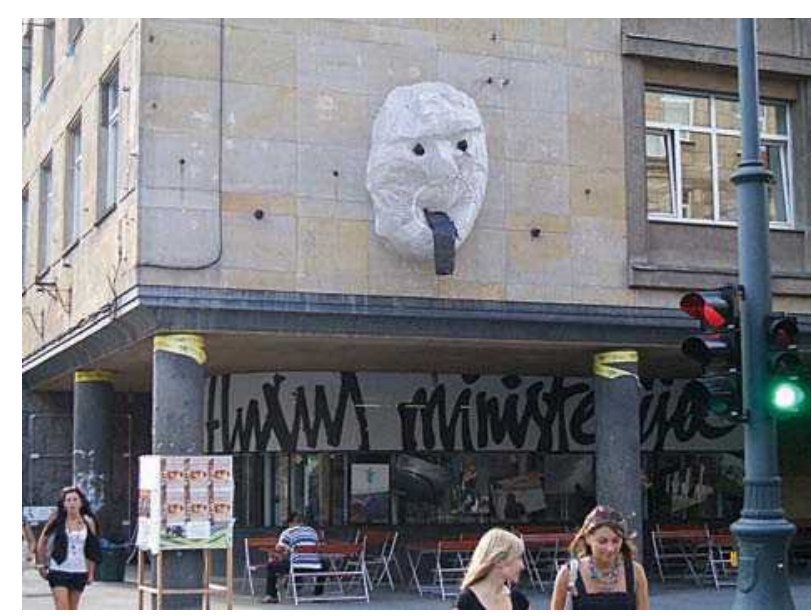

16 pav. „Fluxus ministerija“, Vilnius, $2010 \mathrm{~m}$.

Fig. 16. Fluxus Ministry, Vilnius 2010

dalyvaujančių jaunųjų menininkų santykis su Lietuvos politinemis aktualijomis? Panašu, kad išoriškai deklaruojantis demokratines laisves imitacinis socialiai angažuoto aktyvumo meninis projektas realybeje politiniais tikslais aproprijuoja ne tik fluxus sąjūdị bet ir nūdienos jaunuosius Lietuvos kūrèjus bei jų publiką.

\section{Išvados}

1981 m. NYC Federalinëje aikštèje pastatyta Richad Serra "Išlenkta arka" (Tilted Arc) - milžiniška surūdijusio plieno plokšte - kirto aikštę ir koregavo praeivių maršrutus, neobrutaliai keite aplinkos vaizdą. Dèl aplinkinių pastatų darbuotojų ir gyventojų protestų prasidejęs teismo procesas truko kelerius metus, po jo 1989 m. kūrinys buvo išardytas. Menininkas neleido jo perkelti niekur kitur ir pareikalavo kūrinị supjaustyti. O $2008 \mathrm{~m}$. tapačios neobrutalios raiškos menininko kūrinys „Clara-Clara“ (1983 m.), instaliuotas Paryžiaus širdyje, Eliziejaus laukų prieigose, Tiulri soduose, kèlè didelị publikos susidomejjimą. Šis pavyzdys leidžia daryti prielaidą, kad Jose Ortega y Gasset pastebejjimas apie masių daugumos neigiamą požiūrị i naująji meną laikui bègant keičiasi.

Reikia tikètis, kad laikui bėgant taip atsitiks ir Lietuvoje. Apibendrinant straipsnyje aptartus kūrèjo, užsakovo ir publikos ịvairèjančių vertybių kaitos bei sandraugos ypatumus bei atsižvelgiant i gyvają nagrinejjamo proceso raidą tikslinga pateikti trumpą naujos nepriklausomybès laikų meno viešosiose miesto erdvèse stiprybių, silpnybių, grèsmių bei galimybių analizę.

Stiprybès. Pasireiškianti kūrybinès raiškos ịvairovė nuo posovietinių paminklų iki postmodernistinių site specific skulptūrinių objektų bei socialiai angažuotų projektų viešosiose miesto erdvèse.
Greta konservatyvių valstybinių užsakymų pasireiškia platų meninių sprendimų spektrą atspindinti bei skirtingų poreikių publikos lūkesčius atitinkanti privačių paminklų ar skulptūrinių objektų užsakymų viešosiose miesto erdvèse praktika.

Pirmąjį nepriklausomybès dešimtmetị dainuojančią revoliuciją i̇vykdžiusi visuomenè išgyveno pasitenkinimo naujomis galimybèmis bei permainų, lūkesčių tarpsni, pasireiškusį smalsia tolerancija kūrybinès raiškos įvairovei.

Silpnybès. Valstybè, išlikdama pagrindine meno kūrinių viešosiose erdvèse užsakove bei siekdama išpildyti didžiosios daugumos lūkesčius, naudoja senus, posovietinius sprendimų priemimo metodus.

Dominuojanti bulvarinè (užsakomoji) žiniasklaida neatlieka simbolinių vartų vaidmens, skatinančio visuomenès (publikos) tolerantiškumą meninès raiškos ¡̇vairovei. Mat didejjant įtampai dèl valstybinių subsidijų perskirstymo tarp senų ir naujų politinių grupuočių žiniasklaida ịtraukia kultūrą ì politinių, ekonominių skandalų lauką (pvz.: projekto VEKS 2009 žlugdymo viešųjų ryšių akcija), t. y. tikslingai stiprina kūrejjų ir publikos supriešinimą.

Yra motyvuoto kūrejjų ir publikos dialogo, supratimo stygius. İtraukiantys ị kūrybinị procesą publiką, naujų socialiai angažuoto aktyvumo projektų kūrẻjai, pasiekę meninị, o ne užsibrèžtą socialinị tikslą, neišpildo publikos lūkesčiu („Protesto laboratorija“ neišgelbejjo „Lietuvos“ kino teatro, o „Fluxus ministerija“ tampa paslèptos politinès rinkimų kampanijos erdve).

Grèsmès. Net ir sprogusstatybų rinkos burbului, išlieka spartausviešosios miesto erdvės privatizacijos pavojus.

Užsitęsęs kūrybinių bendruomenių susipriešinimas, siekis ne meninèmis, o politinèmis, ekonominèmis, rinkodaros bei viešųjų ryšių priemonemis užsitikrinti užsakymus smukdo naujų kūrinių viešosiose miesto erdvèse kokybę (Tado Gutausko paminklas „Laisvès kelias“, $2010 \mathrm{~m}$.).

Visuomenejje ịsitvirtinant vartotojiškiems ịpročiams, paklausiausia daugumos laisvalaikio ir viešu pramogų erdve išlieka didieji prekybos centrai.

Galimybès. Vertètų skelbti moratoriumą naujų paminklų statybai, atkreipti dèmesị $\mathfrak{i}$ kitas, tarkime, visuomeninių pastatų (bibliotekų, ligoninių, senelių prieglaudų ir kt.) atminties ịamžinimo formas.

Reikètų depolitizuoti ir liberalizuoti kūrèjo bei užsakovo santykius, skatinti kūrejjus, užsakovus bei miesto bendruomenes suvienijančius projektus (gyvenamųjų rajonų viešųjų erdvių atnaujinimo, žaliųjų laisvalaikio zonų plètros ir kt.).

Būtina sutelkti dèmesị i visuomenès (publikos) meninį ugdymą ir kultūrinị švietimą, t. y. stiprinti analitinès bei nišinès (kultūrinès) žiniasklaidos pozicijas. 


\section{Literatūra}

Donskis, L. 1993. Kultūrinè situacija: Vakarai ir Lietuva II, Metmenys 65: 114-121

Dragisevič-Šešič, M. 1998. Kultūros vadybos įvadas, Kultūros aktualijos (5/7): 12-24.

Girnius, K. 1999. Pilietinè visuomenè Lietuvoje, Naujasis Židinys-Aidai (11-12): 589-900.

Jameson, F. 1983-1998. Postmodernizmas ir vartotojiška visuomene, iš The Cultural Turn: Selected Writings of the Postmodern (4), iš anglų kalbos vertè N. Norkūnienè [žiūrèta $2010 \mathrm{~m}$. gruodžio $5 \mathrm{~d}$.]. Prieiga per internetą: $<\mathrm{http}: / /$ skaitykla.atspace.org/knygos/Frederic_Jameson.pdf $>$.

Jankevičiūtè, G. 1992. Žmogaus ịvaizdžio kaita skulptūroje, iš Šiuolaikines lietuviu dailes horizontai. Vilnius: Academia, 56-71.

Knight, C. K. 2008. Public Art. Theory, Practice and Populism. Blackwell Publishing. 187.

Kotler, P., ir kt. 2003. Rinkodaros principai. Kaunas: Poligrafija ir informatika.

Krauss, R. 1979. Sculpture in the Expanded Field. October, vol. 8: 30-44 [žiūrèta $2010 \mathrm{~m}$. liepos 1 d.]. Prieiga per internetą: $<$ http://links.jstor.org/sici?sici=01622870\%28197921\%298\%3C30\%3ASITEF\%3E2.0.Co\% 3B2-Y>.

Kreivytė, L. 1997. Plastinès raiškos alternatyvų paieškos, iš Skulptūra 1975-1999, sudarytojos G. Jankevičiūtè, E. Lubytè. Vilnius: Aidai, 32-36.

Lubytè, E. 2008. „Arx Baltica“ spaudos namai. Permainu svoris. Dailes vadyba Lietuvoje 1988-2006. Vilnius.

Marshal, G. 1994. The concise Oxford dictionary of Sociology. Oxford. 399.

Novickas, A. 2010. Atminties ịprasminimas miesto aikštèje: nuo paminklo iki patirčiu erdvés: mokomoji knyga. Vilnius: Technika. 80 p. doi:10.3846/1131-S

Ortega y Gasset, J. 1999. Mūsų laikų tema ir kitos ese. Vilnius: Vaga.

Trilupaitytè, S. Kultūros politikos klausimas: finansuoti kultūros įstaigas ar kultūros gyvenimą. Su Prezidento patarejja Irena Vaišvilaite kalbasi Skaidra Trilupaitytė, Kultūros barai (1): 13-17.

Žadeikaitė, R. 2009. J. Ivanauskaitės katinas iš Pašiaušès, Šiaulių kraštas 2009 (08 17) [interaktyvus], [žiūrèta $2010 \mathrm{~m}$. gruodžio 5 d.]. Prieiga per internetą: $<\mathrm{http}: / / \mathrm{www}$. ve.lt/naujienos/kultura/kulturos-naujienos/j-ivanauskaites-katinas-is-pasiauses-54683/>.

\section{ART IN PUBLIC URBAN SPACES: \\ VALUE INTEGRITY BETWEEN AUTHORS, CUSTOMERS AND THE PUBLIC}

\section{E. Lubytè}

Abstract. Public urban spaces reflect the values of society (authors, customers and the public). During transition from the soviet state-planned economy towards market-driven relations, or, in other words, moving from the politically-determined way towards a democratic variety of creative expression, a system of centralized state contracts is being substituted by a more liberal way of contracting works of art in public spaces.

As a consequence, nowadays a public urban space should turn into a platform for representation of various artistic programs that are based on different world outlook values. However, in so far, relations between the authors of various artistic programs, their contracting authorities, and the public are undergoing rather the stage of "cold war" than democratic tolerance (those who are not with us are against us).

While examining the reasons of this phenomenon by research methodologies of social sciences (marketing, management), including PEST, SWOT, case analyses, the paper discusses links of the world outlook values of the author, customer and the public with expression of the contemporary sculpture in public urban spaces (starting with monumental representation and moving towards the site-specific art objects and socially engaged art). To this end, the focus is turned to the reasons of contradictions between values in various contemporary artistic programs and partnership patterns (post-soviet, liberal, new left-wing, learning from Las Vegas, political appropriation).

Keywords: art in public urban space, author, customer, the public, post-soviet; liberal, new left-wing, learning from Las Vegas, political appropriation.

\section{ELONA LUBYTE்}

PhD (social sciences), Assoc. Prof., (2009) UNESCO Dept of Culture Management and Culture Policy, Vilnius Academy of Fine Arts, Maironio g. 6, 01124 Vilnius, Lithuania. E-mail.: lelona@email.lt

First degree, Lithuanian State Art Institute, Dept of Art History, 1987. 1991-2001 a lecturer at the first private art school, run by Jürate Stauskaite. Since 1987 the curator of Lithuanian contemporary sculpture in the Lithuanian Art Museum. Takes part in the arrangement of exhibitions, writes about Lithuanian contemporary art and art management, participates in republican and international conferences.

Social activity: Since 1991 the member of AICA Lithuanian section. 1998-2004 the President of AICA Lithuanian section. 